This PDF is a selection from an out-of-print volume from the National Bureau of Economic Research

Volume Title: New Developments in Productivity Analysis

Volume Author/Editor: Charles R. Hulten, Edwin R. Dean and Michael J. Harper, editors

Volume Publisher: University of Chicago Press

Volume ISBN: 0-226-36062-8

Volume URL: http://www.nber.org/books/hult01-1

Publication Date: January 2001

Chapter Title: Whatever Happened to Productivity Growth?

Chapter Author: Dale Jorgenson, Eric Yip

Chapter URL: http://www.nber.org/chapters/c10133

Chapter pages in book: (p. $509-540)$ 


\title{
Whatever Happened to Productivity Growth?
}

\author{
Dale W. Jorgenson and Eric Yip
}

\subsection{Introduction}

In this paper we present international comparisons of patterns of economic growth among the $\mathrm{G} 7$ countries over the period 1960-95. Between 1960 and 1973 productivity growth accounted for more than half of growth in output per capita for France, Germany, Italy, Japan, and the United Kingdom and somewhat less than half of output growth in Canada and the United States. The relative importance of productivity declined substantially after 1973, accounting for a predominant share of growth between 1973 and 1989 only for France.

Since 1989 productivity growth has almost disappeared as a source of economic growth in the G7 countries. Between 1989 and 1995 productivity growth was negative for five of the G7 countries, with positive growth only for Japan and the United States. The level of productivity for Canada in 1995 fell almost to the level first achieved in 1973, and declines in Italy and the United Kingdom brought productivity down to the levels of 1974 and 1978, respectively. Since 1989 input per capita has grown more slowly than the average for the period 1960-89, except for Germany.

The United States has retained its lead in output per capita throughout the period 1960-95. The United States has also led the G7 countries in input per capita, while relinquishing its lead in productivity to France. However, the United States has lagged behind Canada, France, Germany,

Dale W. Jorgenson is the Frederic E. Abbe Professor of Economics at Harvard University. Eric Yip is a consultant at McKinsey and Company.

We gratefully acknowledge financial support by the Program on Technology and Economic Policy of Harvard University. Responsibility for any remaining deficiencies rests solely with the authors. 
Italy, and Japan in the growth of output per capita, surpassing only the United Kingdom. Except for Germany and the United Kingdom, the United States has lagged behind all the G7 countries in growth in input per capita, and U.S. productivity growth has exceeded only that of Canada and the United Kingdom.

Japan exhibited considerably higher growth rates in output per capita and productivity than the other G7 countries from 1960 to 1995, but most of these gains took place before 1973. Japan's productivity level, along with the levels of Germany and Italy, remain among the lowest in the G7. Japan's performance in output per capita owes more to high input per capita than to high productivity. The growth of Japanese input per capita greatly exceeded that for other G7 countries, especially prior to 1973.

During the period 1960-95, economic performance among the G7 countries became more uniform. The dispersion of levels of output per capita fell sharply before 1970 and has declined modestly since then. The dispersion in productivity levels also fell before 1970 and has remained within a narrow range. The dispersion of levels of input per capita has been stable throughout the period 1960-95. However, the relative positions of the $\mathrm{G} 7$ countries have been altered considerably with the dramatic rise of Japan and the gradual decline of the United Kingdom.

We can rationalize the important changes in economic performance that have taken place among the G7 countries on the basis of the neoclassical theory of economic growth, extended to incorporate persistent differences among countries. Productivity growth is exogenous, whereas investment is endogenous to the theory. Obviously, the relative importance of exogenous productivity growth has been greatly reduced, and a more prominent role must be assigned to endogenous investment in tangible assets and human capital.

In section 12.2 we describe the methodology for allocating the sources of economic growth between investment and productivity. We introduce constant quality indexes of capital and labor inputs that incorporate the impacts of investments in tangible assets and human capital. The constant quality index of labor input combines different types of hours worked by means of relative wage rates. The constant quality index of capital input weights different types of capital stocks by rental rates, rather than the asset prices used for weighting capital stocks.

Differences in wage rates for different types of labor inputs reflect investments in human capital through education and training, so that a constant quality index of labor input is the channel for the impact of these investments on economic performance. The constant quality index of capital input includes a perpetual inventory of investments in tangible assets. The index also incorporates differences in rental prices that capture the differential impacts of these investments.

In section 12.3 we analyze the role of investment and productivity as 
sources of growth in the G7 countries over the period 1960-95. We subdivide this period at 1973 to identify changes in performance after the first oil crisis. We employ 1989 as another dividing point to focus on the most recent experience. We decompose growth of output per capita for each country between growth of productivity and growth of input per capita. Finally, we decompose the growth of input per capita into components associated with investments in tangible assets and human capital.

International comparisons reveal important similarities among the G7 countries. Investments in tangible assets and human capital now account for the overwhelming proportion of economic growth in the G7 countries and also explain the predominant share of international differences in output per capita. Heterogeneity in capital and labor inputs and changes in the composition of these inputs over time are essential for identifying persistent international differences and for accounting for growth.

In section 12.4 we test the important implication of the neoclassical theory of growth that relative levels of output and input per capita must converge over time. For this purpose we employ the coefficient of variation to measure convergence of levels of output per capita, input per capita, and productivity among the G7 countries over the period 1960-95. As before, we divide the period at 1973 and 1989. We also analyze the convergence of capital and labor inputs per capita implied by the theory.

In section 12.5 we summarize the conclusions of our study and outline alternative approaches to endogenous growth through broadening the concept of investment. The mechanism for endogenous accumulation of tangible assets captured in Solow's (1956) version of the neoclassical theory provides the most appropriate point of departure. Investments in human capital, especially investment in education, can now be incorporated into the theory. When measures of the output of R\&D activities become available, investment in intellectual capital can be made endogenous.

\subsection{Investment and Productivity}

Ongoing debates over the relative importance of investment and productivity in economic growth coincide with disputes about the appropriate role for the public sector. Productivity can be identified with spillovers of benefits that fail to provide incentives for actors within the private sector. Advocates of a larger role for the public sector hold the position that these spillovers can be guided into appropriate channels by an all-wise and beneficent government. By contrast proponents of a smaller government search for methods of decentralizing investment decisions among participants in the private sector.

Profound differences in policy implications militate against any simple resolution of the debate on the relative importance of investment and productivity. Proponents of income redistribution will not lightly abandon the 
search for a silver bullet that will generate economic growth without the necessity of providing incentives for investment. Advocates of growth strategies based on capital formation will not readily give credence to claims of spillovers to beneficiaries who are difficult or impossible to identify.

To avoid the semantic confusion that pervades popular discussions of economic growth, it is essential to be precise in defining investment. Investment is the commitment of current resources in the expectation of future returns and can take a multiplicity of forms. The distinctive feature of investment as a source of economic growth is that the returns can be internalized by the investor. The most straightforward application of this definition is to investment in tangible assets that creates property rights, including rights to the incomes that accrue to the owners of the assets.

The mechanism by which tangible investments are translated into economic growth is well understood. For example, an investor in a new industrial facility adds to the supply of these facilities and generates a stream of property income. Investment and income are linked through markets for capital assets and their services. The increase in capital input contributes to output growth in proportion to the marginal product of capital. The stream of property income can be divided between capital input and its marginal product. Identifying this marginal product with the rental price of capital provides the basis for a constant quality index of capital input.

The seminal contributions of Becker (1993), Machlup (1962), Mincer (1974), and Schultz (1961) have given concrete meaning to a notion of wealth including investments that do not create property rights. For example, a student enrolled in school or a worker participating in a training program can be viewed as an investor. Although these investments do not create assets that can be bought or sold, the returns to higher educational qualifications or better skills in the workplace can be internalized by the investor.

An individual who completes a course of education or training adds to the supply of people with higher qualifications or skills. The resulting stream of labor income can be divided between labor input and its marginal product. The increase in labor contributes to output growth in proportion to the marginal product. Identifying this marginal product with the wage rate provides the basis for a constant quality index of labor input. Although there are no asset markets for human capital, investments in human and nonhuman capital have in common that returns to these investments can be internalized.

The defining characteristic of productivity as a source of economic growth is that the incomes generated by higher productivity are external to the economic activities that generate growth. Publicly supported R\&D programs are a leading illustration of activities that stimulate productivity 
growth. These programs can be conducted by government laboratories or financed by public subsidies to private laboratories. The resulting benefits are external to the economic units conducting $\mathrm{R} \& \mathrm{D}$. These benefits must be carefully distinguished from the private benefits of $R \& D$ that can be internalized through the creation of intellectual property rights. ${ }^{1}$

The allocation of sources of economic growth between investment and productivity is critical for assessing the explanatory power of growth theory. Only substitution between capital and labor inputs resulting from investment in tangible assets is endogenous in Solow's (1956) neoclassical theory of growth. However, substitution among different types of labor inputs is the consequence of investment in human capital, whereas investment in tangible assets induces substitution among different types of capital inputs. Neither form of substitution is incorporated into Solow's (1957) model of production.

The distinction between substitution and technical change emphasized by Solow (1957) parallels the distinction between investment and productivity as sources of economic growth. However, Solow's definition of investment, like that of Kuznets (1971), was limited to tangible assets. Both specifically excluded investments in human capital by relying on increases in undifferentiated hours of work as a measure of the contribution of labor input.

The contribution of investment in tangible assets to economic growth is proportional to the rental price of capital, which reflects the marginal product of capital. By contrast the asset price of capital reflects the present value of the income from a capital asset over its entire lifetime. Both Kuznets (1971) and Solow (1970) identified the contributions of tangible assets to growth with increases in the stock of capital, weighted by asset prices. By failing to employ the marginal products of tangible assets as weights, Kuznets and Solow misallocated the sources of economic growth between investment in tangible assets and productivity. ${ }^{2}$

Investment can be made endogenous within a neoclassical growth model, whereas productivity growth is exogenous. If productivity greatly predominates among sources of growth, as indicated by Kuznets (1971) and Solow (1970), most of growth is determined exogenously. Reliance on the Solow residual as an explanatory factor is a powerful indictment of the limitations of the neoclassical framework. This viewpoint was expressed by Abramovitz (1956), who famously characterized the Solow residual as a measure of our ignorance.

Jorgenson and Griliches (1967) introduced constant quality indexes of capital and labor inputs and a constant quality measure of investment

1. Griliches (1992, 1995) has provided detailed surveys of spillovers from R\&D investment. Griliches (1992) gives a list of survey papers on spillovers.

2. The measurement conventions of Kuznets and Solow remain in common use. See, for example, Hall and Jones (1999) and the references given by Jorgenson (1990). 
goods output in allocating the sources of growth between investment and productivity. This greatly broadened the concept of substitution employed by Solow (1957) and altered, irrevocably, the allocation of economic growth between investment and productivity. They showed that 85 percent of U.S. economic growth could be attributed to investment, whereas productivity accounted for only 15 percent (Jorgenson and Griliches 1967, table IX, p. 272).

The measure of labor input employed by Jorgenson and Griliches combined different types of hours worked, weighted by wage rates, into a constant quality index of labor input, using methodology that Griliches (1960) had developed for U.S. agriculture. ${ }^{3}$ Their constant quality index of capital input combined different types of capital inputs by means of rental rates, rather than the asset prices appropriate for measuring capital stock. This model of capital as a factor of production was introduced by Jorgenson (1963) and made possible the incorporation of differences in capital consumption and the tax treatment of different types of capital income. ${ }^{4}$

Jorgenson and Griliches identified technology with a production possibility frontier. This extended the aggregate production function-introduced by Douglas (1948) and developed by Tinbergen (1959) and Solow (1957) - to include two outputs, investment and consumption goods. Jorgenson (1966) showed that economic growth could be interpreted, equivalently as embodied in investment in the sense of Solow (1960) or disembodied in productivity growth. Jorgenson and Griliches removed this indeterminacy by introducing constant quality price indexes for investment goods.

Greenwood, Hercowitz, and Krusell (1997) have recently revived Solow's (1960) concept of embodied technical change. Greenwood, Hercowitz, and Krusell have applied the constant quality indexes for producers' durable equipment constructed by Gordon (1990) to capital input, but not to the output of investment goods, as Gordon did. Within the framework presented by Jorgenson (1966) both the output of investment goods and the input of capital services must be revised in order to hold the quality of investment goods constant. This approach has been employed by Jorgenson and Stiroh $(1995,1999)$ in assessing the impact of investment in information technology. For this purpose they employ constant quality price indexes for computers and related equipment from the U.S. National Income and Product Accounts.

3. Constant quality indexes of labor input are discussed in detail by Jorgenson, Gollop, and Fraumeni (1987), Chapters 3 and 8, pp. 69-108 and 261-300; Bureau of Labor Statistics (BLS; 1993); and Ho and Jorgenson (1999).

4. Detailed surveys of empirical research on the measurement of capital input are given by Jorgenson (1996) and Triplett (1996). BLS (1983) compiled a constant quality index of capital input for its official estimates of productivity, renamed multifactor productivity. BLS retained hours worked as a measure of labor input until 11 July 1994, when it released a new multifactor productivity measure incorporating a constant quality index of labor input. 
Christensen and Jorgenson $(1969,1970)$ imbedded the measurement of productivity in a complete system of U.S. national accounts. They provided a much more detailed model of capital input based on the framework for the taxation of corporate capital income developed by Hall and Jorgenson (1967, 1969, 1971). Christensen and Jorgenson extended this framework to include noncorporate and household capital incomes. This captured the impact of differences in returns to different types of capital inputs more fully.

Christensen and Jorgenson identified the production account with a production possibility frontier describing technology and the income and expenditure account with a social welfare function describing consumer preferences. Following Kuznets (1961), they divided the uses of economic growth between consumption and saving. They linked saving to the wealth account through capital accumulation equations for each type of asset. Prices for different vintages of assets were linked to rental prices of capital inputs through a parallel set of capital asset pricing equations.

In 1973 Christensen and Jorgenson constructed internally consistent income, product, and wealth accounts. Separate product and income accounts are integral parts of both the U.S. National Income and Product Accounts $^{5}$ and the United Nations' (1968) System of National Accounts designed by Stone. ${ }^{6}$ However, neither system included wealth accounts consistent with the income and product accounts.

Christensen and Jorgenson constructed income, product, and wealth accounts, paralleling the U.S. National Income and Product Accounts for the period 1929-69. They also implemented a vintage accounting system for the United States on an annual basis. The complete system of vintage accounts gave stocks of assets of each vintage and their prices. The stocks were cumulated to obtain asset quantities, providing the perpetual inventory of assets employed by Goldsmith $(1955-56,1962)$.

The key innovation was the use of asset pricing equations to link the prices used in evaluating capital stocks and the rental prices employed in the constant quality index of capital input. ${ }^{7}$ In a prescient paper on the measurement of welfare, Samuelson (1961) had suggested that a link between asset and rental prices was essential for the integration of income

5. See Bureau of Economic Analysis (BEA; 1995).

6. The United Nations System of National Accounts (SNA) is summarized by Stone (1992) in his Nobel Prize address. The SNA has been revised by the Inter-Secretariat Working Group on National Accounts (1993).

7. Constant quality price indexes for investment goods of different ages or vintages were developed by Hall (1971). This made it possible for Hulten and Wykoff (1982) to estimate relative efficiencies by age for all types of tangible assets, putting the measurement of capital consumption required for constant quality index of capital input onto a firm empirical foundation. The BEA (1995) has adopted this approach in the latest benchmark revision of the U.S. National Income and Product Accounts, following methodology described by Fraumeni (1997). 
Table 12.1

Disaggregation of Capital by Asset Characteristics

\begin{tabular}{l|l}
\hline Asset Type & Ownership Sector \\
\hline 1. Equipment & 1. Corporations and government \\
2. Nonresidential structures & 2. Unincorporated businesses \\
3. Residential structures & 3. Households and nonprofit institutions \\
4. Nonfarm inventories & 4. General government \\
5. Farm inventories & \\
6. Consumer durables & \\
7. Residential land & \\
8. Nonresidential land & \\
\hline
\end{tabular}

and wealth accounting. ${ }^{8}$ The vintage system of accounts employed the specific form of this relationship developed by Jorgenson (1967).

Christensen, Cummings, and Jorgenson (1980) presented annual estimates of sources of economic growth for the United States and its major trading partners for the period 1960-1973. These estimates included constant quality indexes of capital and labor input for each country. Christensen, Cummings, and Jorgenson (1981) gave relative levels of output, input, and productivity for these same countries for the period 1960-1973, also based on constant quality indexes. Our first objective in this paper is to extend these estimates to 1995 for the G7 countries. ${ }^{9}$ We have chosen GDP as a measure of output. We include imputations for the services of consumers' durables as well as land, buildings, and equipment owned by nonprofit institutions in order to preserve comparability in the treatment of income from different types of capital.

Our constant quality index of capital input is based on a disaggregation of the capital stock among the categories given in table 12.1, classified by asset type and ownership in order to reflect differences in capital consumption and tax treatment among assets. We derive estimates of capital stock and property income for each type of capital input from national accounting data. Similarly, our constant quality index of labor input is based on a disaggregation of the work force among the categories presented in table 12.2, classified by sex, educational attainment, and employment status. For each country we derive estimates of hours worked and labor compensation for each type of labor input from labor force surveys.

\subsection{Sources of Growth}

In table 12.3 we present output per capita annually for the $\mathrm{G} 7$ countries over the period 1960-95, expressed relative to the United States in 1985.

8. See Samuelson (1961), especially p. 309.

9. Dougherty and Jorgenson (1996, 1997) have updated the estimates of Christensen, Cummings, and Jorgenson $(1980,1981)$ through 1989. 
Table 12.2 Disaggregation of Labor by Demographic Characteristics

Sex:

Educational Attainment:

1. One to eight years grade school

2. One to three years secondary school

3. Completed secondary school

4. One to three years college

5. Four or more years of college

Employment Status:

1. Business sector employee

2. Self-employed or unpaid family worker

3. General government employee

Table 12.3 Levels of Output and Input per Capita and Productivity (U.S. $=100.0$ in 1985)

\begin{tabular}{|c|c|c|c|c|c|c|c|}
\hline & $\begin{array}{l}\text { United } \\
\text { States }\end{array}$ & Canada & $\begin{array}{l}\text { United } \\
\text { Kingdom }\end{array}$ & France & Germany & Italy & Japan \\
\hline \multicolumn{8}{|c|}{ Output per Capita } \\
\hline 1960 & 55.6 & 43.1 & 37.5 & 29.2 & 32.9 & 22.7 & 17.3 \\
\hline 1973 & 80.9 & 65.4 & 53.6 & 50.9 & 53.6 & 41.4 & 54.0 \\
\hline 1989 & 109.7 & 96.7 & 70.8 & 70.6 & 75.6 & 63.7 & 83.3 \\
\hline 1995 & 116.3 & 94.6 & 72.6 & 74.6 & 83.5 & 69.2 & 92.8 \\
\hline \multicolumn{8}{|c|}{ Input per Capita } \\
\hline 1960 & 70.2 & 55.6 & 53.0 & 42.5 & 61.7 & 44.8 & 50.1 \\
\hline 1973 & 85.6 & 69.4 & 60.1 & 56.3 & 72.5 & 49.7 & 68.6 \\
\hline 1989 & 108.0 & 98.8 & 71.7 & 63.3 & 88.5 & 73.2 & 96.7 \\
\hline 1995 & 112.5 & 100.1 & 77.5 & 68.7 & 98.5 & 80.1 & 106.7 \\
\hline \multicolumn{8}{|c|}{ Productivity } \\
\hline 1960 & 79.2 & 77.5 & 70.9 & 68.8 & 53.4 & 50.7 & 34.5 \\
\hline 1973 & 94.5 & 94.3 & 89.1 & 90.5 & 73.9 & 83.3 & 78.7 \\
\hline 1989 & 101.6 & 97.9 & 98.8 & 111.5 & 85.4 & 87.0 & 86.1 \\
\hline 1995 & 103.4 & 94.5 & 93.7 & 108.6 & 84.8 & 86.5 & 87.0 \\
\hline
\end{tabular}

For completeness we present output and population separately in tables 12.4 and tables 12.5. We use 1985 purchasing power parities (PPPs) from the OECD (1987) to convert quantities of output per capita from domestic currencies for each country into U.S. dollars. The United States was the leader in per capita output throughout the period, and Canada ranked second for most of the period. Among the remaining five countries the United Kingdom started at the top and Japan at the bottom; by 1995 these roles were interchanged with Japan overtaking all four European countries and the United Kingdom lagging behind France and Germany.

In table 12.3 we present input per capita annually for the G7 countries over the period 1960-95, relative to U.S. input per capita in 1985 . We express quantities of input per capita in U.S. dollars, using PPPs constructed 
Growth Rate and Level in Output

\begin{tabular}{|c|c|c|c|c|c|c|c|}
\hline & $\begin{array}{l}\text { United } \\
\text { States }\end{array}$ & Canada & $\begin{array}{l}\text { United } \\
\text { Kingdom }\end{array}$ & France & Germany & Italy & Japan \\
\hline \multicolumn{8}{|c|}{ Growth Rate (percentage) } \\
\hline $1960-73$ & 4.11 & 4.99 & 3.28 & 5.28 & 4.60 & 5.29 & 9.95 \\
\hline 1973-89 & 2.94 & 4.79 & 1.40 & 2.97 & 2.67 & 4.36 & 3.79 \\
\hline 1973-95 & 2.83 & 2.98 & 2.15 & 2.28 & 1.85 & 2.18 & 3.31 \\
\hline $1989-95$ & 2.00 & 0.94 & 0.78 & 1.49 & 2.45 & 1.32 & 2.14 \\
\hline $1960-89$ & 3.43 & 4.26 & 2.50 & 3.77 & 3.25 & 4.03 & 6.39 \\
\hline $1960-95$ & 3.18 & 3.69 & 2.21 & 3.38 & 3.12 & 3.56 & 5.66 \\
\hline \multicolumn{8}{|c|}{ Level (billions of 1985 U.S. dollars) } \\
\hline 1960 & 1,826 & 140 & 357 & 243 & 332 & 207 & 292 \\
\hline 1973 & 3,115 & 268 & 547 & 482 & 603 & 412 & 1,066 \\
\hline 1989 & 4,930 & 481 & 738 & 724 & 852 & 666 & 1,863 \\
\hline 1995 & 5,560 & 509 & 773 & 791 & 987 & 721 & 2,118 \\
\hline \multicolumn{8}{|c|}{ Level (U.S. $=100.0$ in 1985) } \\
\hline 1960 & 42.1 & 3.2 & 8.2 & 5.6 & 7.7 & 4.8 & 6.7 \\
\hline 1973 & 71.9 & 6.2 & 12.6 & 11.1 & 13.9 & 9.5 & 24.6 \\
\hline 1989 & 113.8 & 11.1 & 17.0 & 16.7 & 19.7 & 15.4 & 43.0 \\
\hline 1995 & 128.3 & 11.7 & 17.8 & 18.3 & 22.8 & 16.6 & 48.9 \\
\hline
\end{tabular}

Table 12.5

Growth Rate and Level in Population

\begin{tabular}{|c|c|c|c|c|c|c|c|}
\hline & $\begin{array}{l}\text { United } \\
\text { States }\end{array}$ & Canada & $\begin{array}{l}\text { United } \\
\text { Kingdom }\end{array}$ & France & Germany & Italy & Japan \\
\hline \multicolumn{8}{|c|}{ Growth Rate (percentage) } \\
\hline $1960-73$ & 1.22 & 1.79 & 0.54 & 1.01 & 0.86 & 0.67 & 1.18 \\
\hline $1973-89$ & 1.00 & 1.22 & 0.01 & 0.47 & -0.17 & 0.45 & 1.07 \\
\hline $1973-95$ & 0.94 & 1.20 & 0.20 & 0.51 & 0.11 & 0.22 & 0.61 \\
\hline 1989-95 & 1.03 & 1.31 & 0.36 & 0.57 & 0.79 & -0.07 & 0.33 \\
\hline $1960-89$ & 1.08 & 1.47 & 0.31 & 0.73 & 0.39 & 0.47 & 0.96 \\
\hline $1960-95$ & 1.07 & 1.44 & 0.32 & 0.70 & 0.46 & 0.38 & 0.85 \\
\hline \multicolumn{8}{|c|}{ Level } \\
\hline 1960 & 180.8 & 17.9 & 52.4 & 45.7 & 55.4 & 50.2 & 93.3 \\
\hline 1973 & 211.9 & 22.6 & 56.2 & 52.1 & 62.0 & 54.8 & 108.7 \\
\hline 1989 & 247.3 & 27.4 & 57.4 & 56.4 & 62.1 & 57.5 & 123.1 \\
\hline 1995 & 263.2 & 29.6 & 58.6 & 58.4 & 65.1 & 57.3 & 125.6 \\
\hline \multicolumn{8}{|c|}{ Level (U.S. = 100.0 in 1985) } \\
\hline 1960 & 75.8 & 7.5 & 22.0 & 19.2 & 23.2 & 21.1 & 39.1 \\
\hline 1973 & 88.9 & 9.5 & 23.6 & 21.9 & 26.0 & 23.0 & 45.6 \\
\hline 1989 & 100.0 & 10.9 & 23.8 & 23.2 & 25.6 & 24.0 & 50.6 \\
\hline 1995 & 110.4 & 12.4 & 24.6 & 24.5 & 27.3 & 24.0 & 52.7 \\
\hline
\end{tabular}


for this study. ${ }^{10}$ The United States was the leader in per capita input as well as output throughout the period. Germany started in second place but lost its position to Canada in 1975 and Japan in 1976. In 1995 Japan ranked next to the United States in input per capita with Canada third. France started at the bottom of the ranking and remained there for most of the period. Canada, France, Italy, and Japan grew relative to the United States, whereas Germany and the United Kingdom declined.

In table 12.3 we present productivity levels annually for the G7 countries over the period 1960-95, where productivity is defined as the ratio of output to input. In 1960 the United States was the productivity leader with Canada closely behind. In 1970 Canada became the first country to overtake the United States, remaining slightly above the U.S. level for most of the period ending in 1984. France surpassed the U.S. in 1979 and became the international productivity leader after 1980. The United Kingdom overtook Canada and nearly overtook the United States in 1987, but fell behind both countries in 1990. Japan surpassed Germany in 1970 and Italy in 1990, and Italy overtook Germany in 1963 and maintained its lead during most of the period ending in 1995.

We summarize growth in output and input per capita and productivity for the G7 countries in table 12.6. (For completeness we present growth rates of output and population separately in tables 12.4 and 12.5.) We present annual average growth rates for the period 1960-95 and the subperiods 1960-73, 1973-89, and 1989-95. Japan was the leader in output growth for the period as a whole and before 1973. The United Kingdom grew more slowly than the remaining six countries during the period as a whole and after 1960. Output growth slowed in all the G7 countries after 1989, and Canada's growth rate was negative. Differences in growth rates among the G7 countries declined substantially after 1973 .

Japan also led the G7 in growth of input per capita for the period 1960-95 and before 1973. Italy was the leader during the subperiod 197389, and Germany led during 1989-95. There is little evidence of a slowdown in input growth after 1973; differences among input growth rates are much less than among output growth rates. Japan led the $\mathrm{G} 7$ in productivity growth for the period as a whole and before 1973, whereas France was the leader from 1973 to 1989 . All the G7 countries-with the exception of Japan and the United States-experienced negative productivity growth after 1989. The United States had a slightly higher productivity growth rate than Japan during this period. In table 12.3 we present levels of output and input per capita and productivity relative to the U.S. level in 1985.

Our constant quality index of capital input weights capital stocks for each of the categories given in table 12.1 by rental prices, defined as property compensation per unit of capital. By contrast, an index of capital

10. Our methodology is described in detail by Dougherty (1992). 


\begin{tabular}{|c|c|c|c|c|c|c|c|}
\hline & $\begin{array}{l}\text { United } \\
\text { States }\end{array}$ & Canada & $\begin{array}{l}\text { United } \\
\text { Kingdom }\end{array}$ & France & Germany & Italy & Japan \\
\hline \multicolumn{8}{|c|}{ Output per Capita } \\
\hline $1960-73$ & 2.89 & 3.20 & 2.74 & 4.26 & 3.74 & 4.62 & 8.77 \\
\hline $1973-89$ & 1.90 & 2.45 & 1.75 & 2.04 & 2.15 & 2.69 & 2.71 \\
\hline $1973-95$ & 1.65 & 1.68 & 1.38 & 1.74 & 2.02 & 2.34 & 2.46 \\
\hline $1989-95$ & 0.97 & -0.37 & 0.42 & 0.92 & 1.66 & 1.40 & 1.81 \\
\hline 1960-89 & 2.34 & 2.79 & 2.19 & 3.04 & 2.86 & 3.56 & 5.43 \\
\hline $1960-95$ & 2.11 & 2.24 & 1.89 & 2.68 & 2.66 & 3.19 & 4.81 \\
\hline \multicolumn{8}{|c|}{ Input per Capita } \\
\hline $1960-73$ & 1.53 & 1.70 & 0.98 & 2.15 & 1.24 & 0.79 & 2.42 \\
\hline $1973-89$ & 1.45 & 2.21 & 1.10 & 0.74 & 1.25 & 2.42 & 2.15 \\
\hline $1973-95$ & 1.24 & 1.67 & 1.15 & 0.91 & 1.39 & 2.17 & 2.01 \\
\hline $1989-95$ & 0.68 & 0.21 & 1.30 & 1.37 & 1.78 & 1.49 & 1.63 \\
\hline $1960-89$ & 1.49 & 1.98 & 1.04 & 1.37 & 1.25 & 1.69 & 2.27 \\
\hline $1960-95$ & 1.35 & 1.68 & 1.09 & 1.37 & 1.34 & 1.66 & 2.16 \\
\hline \multicolumn{8}{|c|}{ Productivity } \\
\hline $1960-73$ & 1.36 & 1.51 & 1.76 & 2.11 & 2.50 & 3.82 & 6.35 \\
\hline 1973-89 & 0.45 & 0.23 & 0.65 & 1.31 & 0.90 & 0.27 & 0.56 \\
\hline $1973-95$ & 0.41 & 0.01 & 0.23 & 0.83 & 0.62 & 0.17 & 0.45 \\
\hline 1989-95 & 0.29 & -0.59 & -0.88 & -0.45 & -0.11 & -0.10 & 0.18 \\
\hline $1960-89$ & 0.86 & 0.80 & 1.15 & 1.67 & 1.62 & 1.86 & 3.16 \\
\hline $1960-95$ & 0.76 & 0.57 & 0.80 & 1.30 & 1.32 & 1.53 & 2.65 \\
\hline
\end{tabular}

stock weights different types of capital by asset prices rather than by the rental prices appropriate for capital input. The ratio of capital input to capital stock measures the average quality of a unit of capital, as reflected in its marginal product. This enables us to assess the magnitude of differences between the constant quality index of capital input and the unweighted index of capital stock employed by Kuznets (1971) and Solow (1970).

In table 12.7 we present capital input per capita annually for the G7 countries over the period 1960-95, expressed relative to the United States in 1985. The United States was the leader in capital input per capita through 1991, when Canada overtook the United States and emerged as the international leader. All countries grew substantially relative to the United States, but only Canada surpassed the U.S. level. Germany led the remaining five countries throughout the period, and the United Kingdom was the laggard among these countries, except for the period 1962-73, when Japan ranked lower.

The picture for capital stock per capita has some similarities to capital input, but there are important differences. The United States led throughout the period in capital stock, whereas Canada overtook the United 
Levels of Capital Input and Capital Stock per Capita and Capital Quality (U.S. = 100.0 in 1985)

\begin{tabular}{|c|c|c|c|c|c|c|c|}
\hline & $\begin{array}{l}\text { United } \\
\text { States }\end{array}$ & Canada & $\begin{array}{c}\text { United } \\
\text { Kingdom }\end{array}$ & France & Germany & Italy & Japan \\
\hline \multicolumn{8}{|c|}{ Capital Input per Capita } \\
\hline 1960 & 58.5 & 41.7 & 21.0 & 24.0 & 26.0 & 17.1 & 21.6 \\
\hline 1973 & 79.0 & 61.9 & 32.4 & 46.8 & 56.6 & 38.4 & 31.6 \\
\hline 1989 & 109.4 & 106.7 & 52.6 & 76.4 & 91.9 & 80.7 & 56.4 \\
\hline 1995 & 114.3 & 119.2 & 60.4 & 87.1 & 108.5 & 97.3 & 68.3 \\
\hline \multicolumn{8}{|c|}{ Capital Stock per Capita } \\
\hline 1960 & 68.2 & 43.3 & 18.8 & 18.8 & 20.1 & 19.6 & 17.3 \\
\hline 1973 & 85.8 & 60.3 & 28.0 & 38.1 & 41.3 & 37.5 & 25.4 \\
\hline 1989 & 105.3 & 93.3 & 42.9 & 63.4 & 62.9 & 65.9 & 47.8 \\
\hline 1995 & 109.4 & 98.5 & 48.2 & 71.8 & 74.9 & 79.6 & 58.7 \\
\hline \multicolumn{8}{|c|}{ Capital Quality } \\
\hline 1960 & 85.8 & 96.3 & 111.8 & 127.2 & 129.1 & 87.6 & 124.7 \\
\hline 1973 & 92.1 & 102.7 & 116.1 & 122.8 & 137.1 & 102.2 & 124.1 \\
\hline 1989 & 103.9 & 114.3 & 122.7 & 120.6 & 146.1 & 122.5 & 118.0 \\
\hline 1995 & 104.5 & 121.0 & 125.2 & 121.3 & 144.8 & 122.2 & 116.3 \\
\hline
\end{tabular}

States in capital input. France, Germany, and Italy had similar stock levels throughout the period with Italy leading this group of three countries in 1995. Similarly, Japan and the United Kingdom had similar levels throughout the period; Japan ranked last until 1976 but surpassed the United Kingdom in that year. Capital stock levels do not accurately reflect the substitutions among capital inputs that accompany investments in tangible assets.

Capital quality is the ratio of capital input to capital stock. The behavior of capital quality highlights the differences between the constant quality index of capital input and capital stock. Germany was the international leader in capital quality throughout most of the period 1960-95, and the United States ranked at the bottom. There are important changes in capital quality over time and persistent differences among countries. Heterogeneity of capital input within each country and between countries must be taken into account in international comparisons of economic performance.

We summarize growth in capital input and capital stock per capita and capita quality for the $\mathrm{G} 7$ countries in table 12.8. Italy was the international leader in capital input growth, and the United States was the laggard for the period 1960-95. There was a modest slowdown in capital input growth after 1973 and again after 1989 as well as similar slowdowns in capital stock growth. Italy was the leader in capital quality growth, and Japan was the laggard. In table 12.7 we present levels of capital input and capital stock per capita and capital quality relative to the United States in 1985.

Our constant quality index of labor input weights hours worked for each 
Table 12.8

Growth in Capital Input and Capital Stock per Capita and Capital

Quality (percentage)

\begin{tabular}{lccccccr}
\hline & $\begin{array}{c}\text { United } \\
\text { States }\end{array}$ & Canada & $\begin{array}{c}\text { United } \\
\text { Kingdom }\end{array}$ & France & Germany & Italy & Japan \\
\hline & & \multicolumn{7}{c}{ Capital Input } & per Capita & & & \\
$1960-73$ & 2.32 & 3.03 & 3.34 & 5.15 & 6.00 & 6.20 & 2.93 \\
$1973-89$ & 2.03 & 3.40 & 3.02 & 3.06 & 3.02 & 4.65 & 3.63 \\
$1973-95$ & 1.68 & 2.98 & 2.82 & 2.82 & 2.95 & 4.23 & 3.51 \\
$1989-95$ & 0.74 & 1.85 & 2.29 & 2.19 & 2.77 & 3.12 & 3.18 \\
$1960-89$ & 2.16 & 3.24 & 3.17 & 4.00 & 4.36 & 5.34 & 3.32 \\
$1960-95$ & 1.92 & 3.00 & 3.02 & 3.69 & 4.09 & 4.96 & 3.29 \\
& & & Capital Stock per Capita & & & \\
$1960-73$ & 1.77 & 2.54 & 3.06 & 5.42 & 5.54 & 5.01 & 2.97 \\
$1973-89$ & 1.28 & 2.73 & 2.68 & 3.17 & 2.63 & 3.52 & 3.94 \\
$1973-95$ & 1.11 & 2.23 & 2.48 & 2.88 & 2.71 & 3.42 & 3.80 \\
$1989-95$ & 0.64 & 0.91 & 1.94 & 2.08 & 2.92 & 3.15 & 3.42 \\
$1960-89$ & 1.50 & 2.65 & 2.85 & 4.18 & 3.93 & 4.18 & 3.51 \\
$1960-95$ & 1.35 & 2.35 & 2.69 & 3.82 & 3.76 & 4.01 & 3.49 \\
& & & Capital Quality & & & \\
$1960-73$ & 0.55 & 0.49 & 0.29 & -0.27 & 0.46 & 1.19 & -0.04 \\
$1973-89$ & 0.75 & 0.67 & 0.35 & -0.11 & 0.40 & 1.13 & -0.32 \\
$1973-95$ & 0.57 & 0.75 & 0.35 & -0.05 & 0.25 & 0.81 & -0.30 \\
$1989-95$ & 0.09 & 0.95 & 0.34 & 0.10 & -0.15 & -0.03 & -0.24 \\
$1960-89$ & 0.66 & 0.59 & 0.32 & -0.18 & 0.43 & 1.16 & -0.19 \\
$1960-95$ & 0.56 & 0.65 & 0.32 & -0.14 & 0.33 & 0.95 & -0.20 \\
\hline
\end{tabular}

of the categories given in table 12.2 by wage rates defined in terms of labor compensation per hour. An index of hours worked adds together different types of hours without taking quality differences into account. The ratio of labor input to hours worked measures the average quality of an hour of labor, as reflected in its marginal product. This enables us to assess the magnitude of differences between the constant quality index of labor input and the unweighted index of hours worked employed by Kuznets (1971) and Solow (1970).

In table 12.9 we present labor input per capita annually for the G7 countries for the period 1960-95, relative to the United States in 1985. The United Kingdom led until 1962 but was overtaken by Japan in that year. The United States surpassed the United Kingdom in 1977, but the two countries grew in parallel through 1995 with the United States maintaining a slight lead over most of the period. France ranked at the bottom of the G7 for most of the period but led Italy from 1965 to 1979. Japan remained the international leader through 1995 with levels of labor input more than one-third of the United States and the United Kingdom and more than double that of France.

The picture for hours worked per capita has some similarities to labor 
Levels of Labor Input and Hours Worked per Capita and Labor Quality (U.S. = 100.0 in 1985)

\begin{tabular}{|c|c|c|c|c|c|c|c|}
\hline & $\begin{array}{l}\text { United } \\
\text { States }\end{array}$ & Canada & $\begin{array}{c}\text { United } \\
\text { Kingdom }\end{array}$ & France & Germany & Italy & Japan \\
\hline \multicolumn{8}{|c|}{ Labor Input per Capita } \\
\hline 1960 & 77.8 & 69.0 & 95.5 & 60.5 & 98.6 & 66.6 & 91.2 \\
\hline 1973 & 89.1 & 75.4 & 89.8 & 63.0 & 84.3 & 56.6 & 117.7 \\
\hline 1989 & 107.0 & 93.0 & 89.3 & 55.2 & 86.1 & 68.7 & 141.0 \\
\hline 1995 & 111.1 & 87.5 & 93.7 & 57.5 & 90.8 & 70.2 & 146.2 \\
\hline \multicolumn{8}{|c|}{ Hours Worked per Capita } \\
\hline 1960 & 91.1 & 80.4 & 110.2 & 105.0 & 120.4 & 89.2 & 134.4 \\
\hline 1973 & 95.5 & 83.7 & 96.6 & 97.4 & 98.7 & 74.6 & 145.3 \\
\hline 1989 & 104.5 & 93.4 & 92.7 & 77.8 & 93.5 & 85.5 & 150.2 \\
\hline 1995 & 105.3 & 84.3 & 92.6 & 74.2 & 95.4 & 84.2 & 152.1 \\
\hline \multicolumn{8}{|c|}{ Labor Quality } \\
\hline 1960 & 85.4 & 85.8 & 86.7 & 57.7 & 81.9 & 74.7 & 67.9 \\
\hline 1973 & 93.3 & 90.1 & 92.9 & 64.7 & 85.4 & 75.9 & 81.0 \\
\hline 1989 & 102.4 & 99.6 & 96.4 & 71.0 & 92.0 & 80.3 & 93.9 \\
\hline 1995 & 105.5 & 103.8 & 101.3 & 77.5 & 95.2 & 83.4 & 96.1 \\
\hline
\end{tabular}

input, but there are important differences. Japan was the international leader in hours worked per capita throughout the period, and Germany led the four European countries for most of the period. The United States overtook France in 1975 and Germany and the United Kingdom in 1977. At the beginning of the period Canada ranked last but lost this position to Italy in 1965. Italy was the laggard in hours worked until 1983, when France fell to the bottom of the G7, remaining there through 1995. Hours worked do not accurately reflect the substitutions among labor inputs that accompany investments in human capital.

Labor quality is the ratio of the constant quality index of labor input to the unweighted index of hours worked. The behavior of labor quality highlights the differences between labor input and hours worked. Canada, the United States, and the United Kingdom were the leaders in labor quality; labor quality in these three countries grew in parallel through 1995. France was the laggard among G7 countries in labor quality throughout most of the period 1960-95. There are important changes in labor quality over time and persistent differences among countries. Heterogeneity within each country and between countries must be taken into account in international comparisons of economic growth.

We summarize growth in labor input and hours worked per capita and labor quality in table 12.10. Japan led the G7 countries in labor input growth for the period 1960-95 and before 1973. Canada was the international leader during the subperiod 1973-89, and Germany was the leader after 1989. The United States led growth in hours worked for the period as a whole and after 1989, and Japan was the leader before 1973, and Italy 
Table 12.10

Growth in Labor Input and Hours Worked per Capita and Labor

Quality (percentage)

\begin{tabular}{lcrrrrrr}
\hline & United & \multicolumn{7}{c}{ United } \\
& States & Canada & Kingdom & France & Germany & Italy & Japan \\
\hline & & \multicolumn{7}{c}{ Labor Input per Capita } & & & \\
$1960-73$ & 1.05 & 0.69 & -0.48 & 0.31 & -1.20 & -1.25 & 1.96 \\
$1973-89$ & 1.14 & 1.31 & -0.03 & -0.82 & 0.13 & 1.21 & 1.13 \\
$1973-95$ & 1.00 & 0.68 & 0.20 & -0.41 & 0.34 & 0.97 & 0.98 \\
$1989-95$ & 0.64 & -1.01 & 0.80 & 0.68 & 0.90 & 0.34 & 0.60 \\
$1960-89$ & 1.10 & 1.03 & -0.23 & -0.32 & -0.47 & 0.11 & 1.50 \\
$1960-95$ & 1.02 & 0.68 & -0.05 & -0.14 & -0.23 & 0.15 & 1.35 \\
& & \multicolumn{7}{c}{ Hours Worked per Capita } & & & \\
$1960-73$ & 0.37 & 0.31 & -1.01 & -0.57 & -1.53 & -1.38 & 0.60 \\
$1973-89$ & 0.56 & 0.69 & -0.26 & -1.41 & -0.34 & 0.86 & 0.21 \\
$1973-95$ & 0.44 & 0.03 & -0.20 & -1.24 & -0.16 & 0.55 & 0.21 \\
$1989-95$ & 0.13 & -1.70 & -0.02 & -0.79 & 0.34 & -0.27 & 0.21 \\
$1960-89$ & 0.47 & 0.52 & -0.60 & -1.03 & -0.87 & -0.15 & 0.38 \\
$1960-95$ & 0.42 & 0.14 & -0.50 & -0.99 & -0.67 & -0.17 & 0.35 \\
& & \multicolumn{7}{c}{ Labor Quality } & & & \\
$1960-73$ & 0.68 & 0.38 & 0.53 & 0.88 & 0.32 & 0.13 & 1.36 \\
$1973-89$ & 0.58 & 0.62 & 0.23 & 0.58 & 0.47 & 0.35 & 0.92 \\
$1973-95$ & 0.56 & 0.64 & 0.39 & 0.83 & 0.50 & 0.42 & 0.78 \\
$1989-95$ & 0.50 & 0.70 & 0.82 & 1.47 & 0.56 & 0.62 & 0.39 \\
$1960-89$ & 0.62 & 0.51 & 0.37 & 0.72 & 0.40 & 0.25 & 1.12 \\
$1960-95$ & 0.60 & 0.55 & 0.44 & 0.85 & 0.43 & 0.31 & 0.99 \\
\hline
\end{tabular}

led between 1973 to 1989 . Growth was positive throughout the period for Japan and the United States, mostly negative for the four European countries, and alternately positive and negative for Canada. Growth in labor quality was positive for all seven countries with a modest decline after 1973 and a revival after 1989. In table 12.9 we present labor input and hours worked per capita and labor quality relative to the U.S. in 1985.

Using data from table 12.6, we can assess the relative importance of investment and productivity in per capita growth for the G7 countries. For Canada, the United Kingdom, and the United States, investments in tangible assets and human capital greatly predominated as sources of growth over the period 1960-95. We can attribute slightly more than half of Japanese growth to productivity, whereas proportions for the four European countries-France, Germany, Italy, and the United Kingdom-are slightly less than half. After 1973 growth in output and productivity declined for all seven countries; however, growth in input has not declined, so the relative importance of productivity has sharply diminished.

Similarly, using data from table 12.8 we can combine estimates of growth in capital input, capital stock, and capital quality to assess the 
importance of changes in quality. Capital input growth is positive for all countries for the period 1960-95 and all three subperiods. Capital quality growth is positive for the period as a whole for all G7 countries, except France and Japan. Although capital stock greatly predominates in capital input growth, capital quality is quantitatively significant, so that the heterogeneity of capital must be taken into account in assessing the role of investment in tangible assets.

Finally, using data from table 12.10 we can combine estimates of growth in labor input, hours worked, and labor quality to assess the importance of hours and quality. Labor input growth is negative for the period 1960-95 in France, Germany, and the United Kingdom and is slightly positive for Italy. Growth in hours worked is mostly negative for all four countries throughout the period. However, growth in labor quality has helped to offset the decline in hours worked in Europe. For Canada, Japan, and the United States, labor quality predominates in the growth of labor input, so that the heterogeneity of labor input is essential in assessing the role of investment in human capital.

\subsection{Convergence}

The objective of modeling economic growth is to explain the sources and uses of growth endogenously. National income is the starting point for assessments of the uses of growth through consumption and saving. The concept of a measure of economic welfare, introduced by Nordhaus and Tobin (1972), is the key to augmenting national income to broaden the concepts of consumption and saving. Similarly, GDP is the starting point for attributing the sources of economic growth to growth in productivity and investments in tangible assets and human capital.

Denison (1967) compared differences in growth rates for national income per person employed for the period 1950-62 with differences of levels in 1960 for eight European countries and the United States. However, he overlooked the separate roles for a production account with the national product and inputs of capital and labor services and an income and expenditure account with national income, consumption, and saving. From an economic point of view this ignored the distinction between the sources and uses of economic growth.

Denison compared differences in both growth rates and levels of national income per person employed. The eight European countries as a whole were characterized by more rapid growth and a lower level of national income per capita. Although this association was not monotonic for comparisons between individual countries and the United States, Denison concluded that ${ }^{11}$

11. See Denison (1967), especially Chapter 21, "The Sources of Growth and the Contrast between Europe and the United States," pp. 296-348. 
Aside from short-term aberrations Europe should be able to report higher growth rates, at least in national income per person employed, for a long time. Americans should expect this and not be disturbed by it.

Kuznets (1971) provided elaborate comparisons of growth rates for the fourteen countries included in his study. Unlike Denison (1967), he did not provide level comparisons. Maddison (1982) filled this gap by comparing levels of national product for sixteen countries ${ }^{12}$ on the basis of estimates of PPPs by Kravis, Heston, and Summers (1978). ${ }^{13}$ These estimates have been updated by successive versions of the Penn World Table and made it possible to reconsider the issue of convergence of output per capita raised by Denison (1967). ${ }^{14}$

Abramovitz (1986) was the first to take up the challenge of analyzing convergence of output per capita among Maddison's sixteen countries. He found that convergence appeared to characterize output levels in the postwar period, but not the period before 1914 and the interwar period. Baumol (1986) formalized these results by running a regression of growth rate of GDP per hour worked over the period 1870-1979 on the 1870 level of GDP per hour worked. ${ }^{15}$ A negative regression coefficient is evidence for beta-convergence of GDP levels.

In a notable paper titled "Crazy Explanations for the Productivity Slowdown," Romer (1987) derived a version of the growth regression from Solow's (1970) growth model with a Cobb-Douglas production function. Romer also extended the data set for growth regressions from Maddison's (1982) group of sixteen advanced countries to the 115 countries included in Penn World Table (Mark 3), presented by Summers and Heston (1984). Romer's key finding was that an indirect estimate of the Cobb-Douglas elasticity of output with respect to capital was close to three-quarters. The share of capital in output implied by Solow's model was less than half as great on average. ${ }^{16}$

12. Maddison added Austria and Finland to Kuznets' list and presented growth rates covering periods beginning as early as 1820 and extending through 1979. Maddison (1991, 1995) has extended these estimates through 1992.

13. For details see Maddison (1982, 159-168). Purchasing power parities were first measured for industrialized countries by Gilbert and Kravis (1954) and Gilbert (1958).

14. A complete list through Mark 5 is given by Summers and Heston (1991), while the results of Mark 6 are summarized by the World Bank (1994) in the World Development Report 1993.

15. This growth regression has spawned a vast literature, summarized by Levine and Renelt (1992); Baumol (1994); and Barro and Sala-i-Martin (1994). Much of this literature has been based on successive versions of the Penn World Table.

16. Unfortunately, this Mark 3 data set did not include capital input. Romer's empirical finding has spawned a substantial theoretical literature, summarized at an early stage by Lucas (1988) and, more recently, by Grossman and Helpman (1991, 1994); Romer (1994); Barro and Sala-i-Martin (1994); and Aghion and Howitt (1998). Romer's own important contributions to this literature have focused on increasing returns to scale, as in Romer (1986), and spillovers from technological change, as in Romer (1990). 
Mankiw, Romer, and Weil (1992) undertook a defense of the neoclassical framework of Kuznets (1971) and Solow (1970). The empirical portion of their study is based on data for ninety-eight countries from the Penn World Table (Mark 4), presented by Summers and Heston (1988). Like Romer (1987), Mankiw, Romer, and Weil derived a growth equation from the Solow (1970) model; however, they also augmented this model by allowing for investment in human capital.

The results of Mankiw, Romer, and Weil (1992) provided empirical support for the augmented Solow model. There was clear evidence of the convergence predicted by the model, where convergence was conditional on the ratio of investment to GDP and the rate of population growth; both are determinants of steady state output. In addition, the estimated CobbDouglas elasticity of output with respect to capital coincided with the share of capital in the value of output. However, the rate of convergence of output per capita was too slow to be consistent with the 1970 version of the Solow model.

Islam (1995) exploited an important feature of the Summers-Heston (1988) data overlooked in previous empirical studies, namely, benchmark comparisons of levels of the national product at five year intervals, beginning in 1960 and ending in 1985. Using econometric methods for panel data, Islam tested an assumption maintained in growth regressions, such as those of Mankiw, Romer, and Weil. Their study, like that of Romer (1987), assumed identical technologies for all countries included in the Summers-Heston data sets.

Substantial differences in levels of productivity among countries have been documented by Denison (1967); Christensen, Cummings, and Jorgenson (1981); and earlier in section 12.2. By introducing panel data techniques, Islam (1995) was able to allow for these differences. He corroborated the finding of Mankiw, Romer, and Weil (1992) that the elasticity of output with respect to capital input coincided with the share of capital in the value of output.

In addition, Islam (1995) found that the rate of convergence of output per capita among countries in the Summers-Heston (1988) data set was precisely that required to substantiate the unaugmented version of the Solow (1970). In short, "crazy explanations" for the productivity slowdown, like those propounded by Romer $(1987,1994)$, are not required. Moreover, the model did not require augmentation, as suggested by Mankiw, Romer, and Weil (1992). However, differences in productivity among these countries must be taken into account in modeling differences in growth rates.

The conclusion from Islam's (1995) research is that the Solow model is the appropriate point of departure for modeling the accumulation of tangible assets. For this purpose it is unnecessary to endogenize investment in human capital as well. The rationale for this key empirical finding is that the transition path to balanced growth equilibrium requires decades after 
changes in policies that affect investment in tangible assets, such as tax policies. By contrast, the transition after changes in policies affecting investment in human capital requires as much as a century.

In figure 12.1 we present coefficients of variation for levels of output and input per capita and productivity for the G7 countries annually for the period 1960-95. The coefficients for output decline by almost a factor of two between 1960 and 1974 but then remain stable throughout the rest of the period. Coefficients for productivity decline by more than a factor of two between 1960 and 1970 and then stabilize. Coefficients for input per capita are nearly unchanged throughout the period. This is evidence

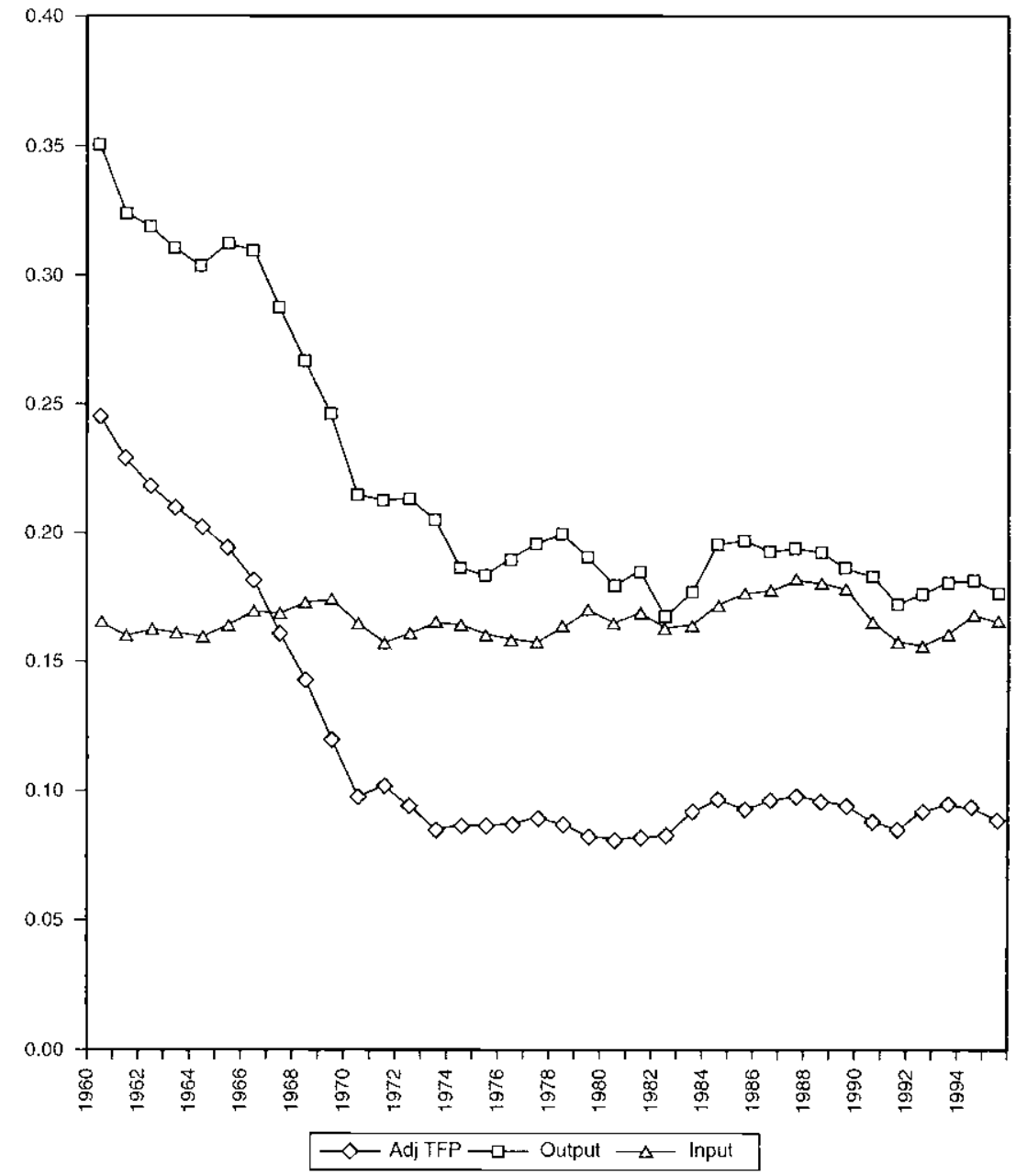

Fig. 12.1 Convergence of output and input per capita and productivity 


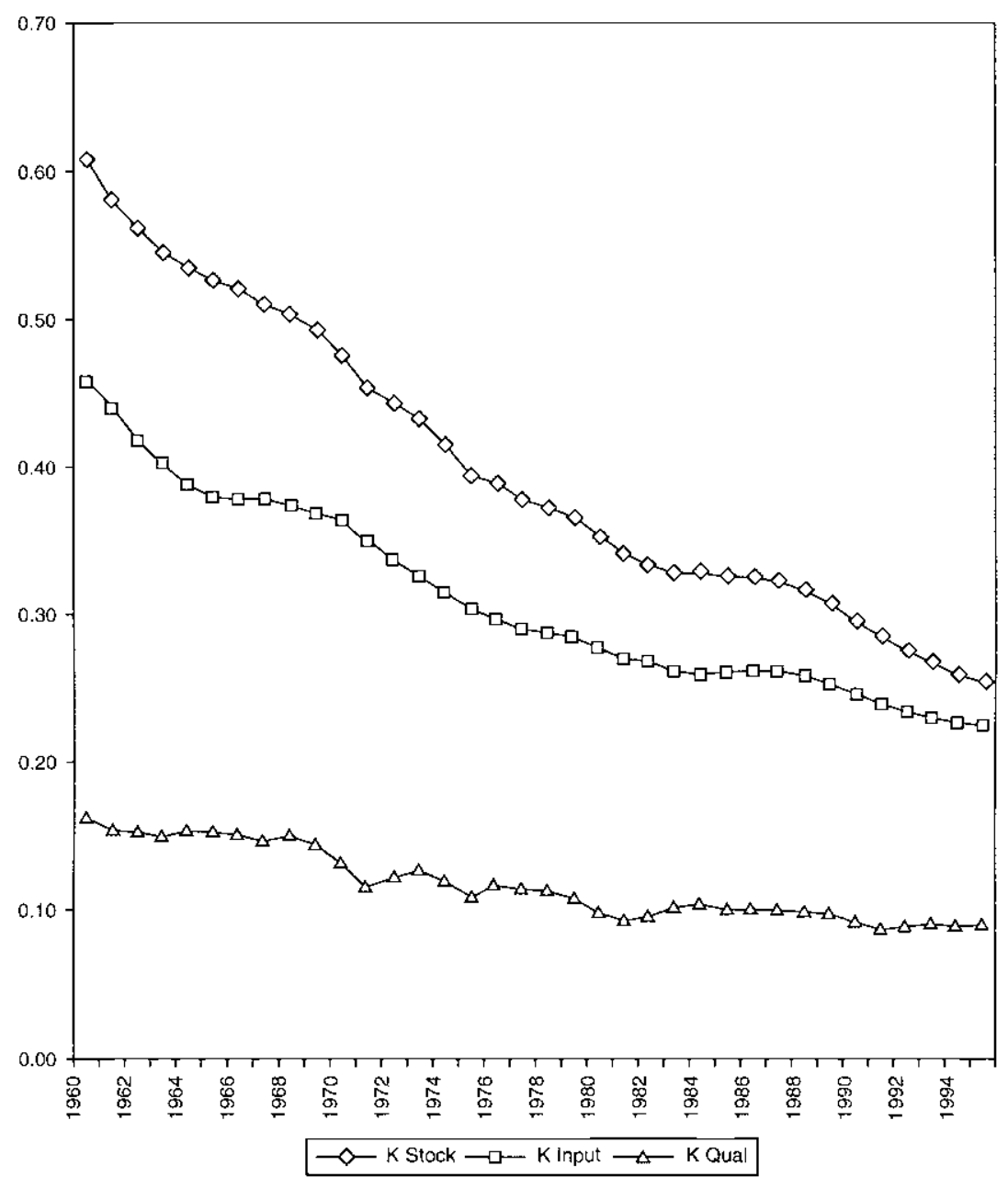

Fig. 12.2 Convergence of capital input, capital stock per capita, and capital quality

for the sigma-convergence of output and input per capita and productivity implied by Solow's neoclassical theory of growth, allowing for differences in productivity of the type identified by Islam.

Figure 12.2 presents coefficients of variation for levels of capital input and capital stock per capita and capital quality for the G7 countries. The coefficients for capital input decline gradually throughout the period. Coefficients for capital stock are slightly larger than those for capital input but behave in a similar manner. Coefficients for capital quality are stable until 1968 and then decline to a slightly lower level after 1971. This is also 
evidence of the sigma-convergence implied by Solow's growth model with persistent differences in levels of capital quality among countries.

Finally, coefficients of variation for levels of labor input and hours worked per capita and labor quality for the G7 are given in figure 12.3. The coefficients for labor input rise gradually. The coefficients for hours worked rise gradually until 1973 and then stabilize for most of the period. The coefficients for labor quality gradually decline. Again, this is evidence for sigma-convergence with persistent international differences in labor quality.

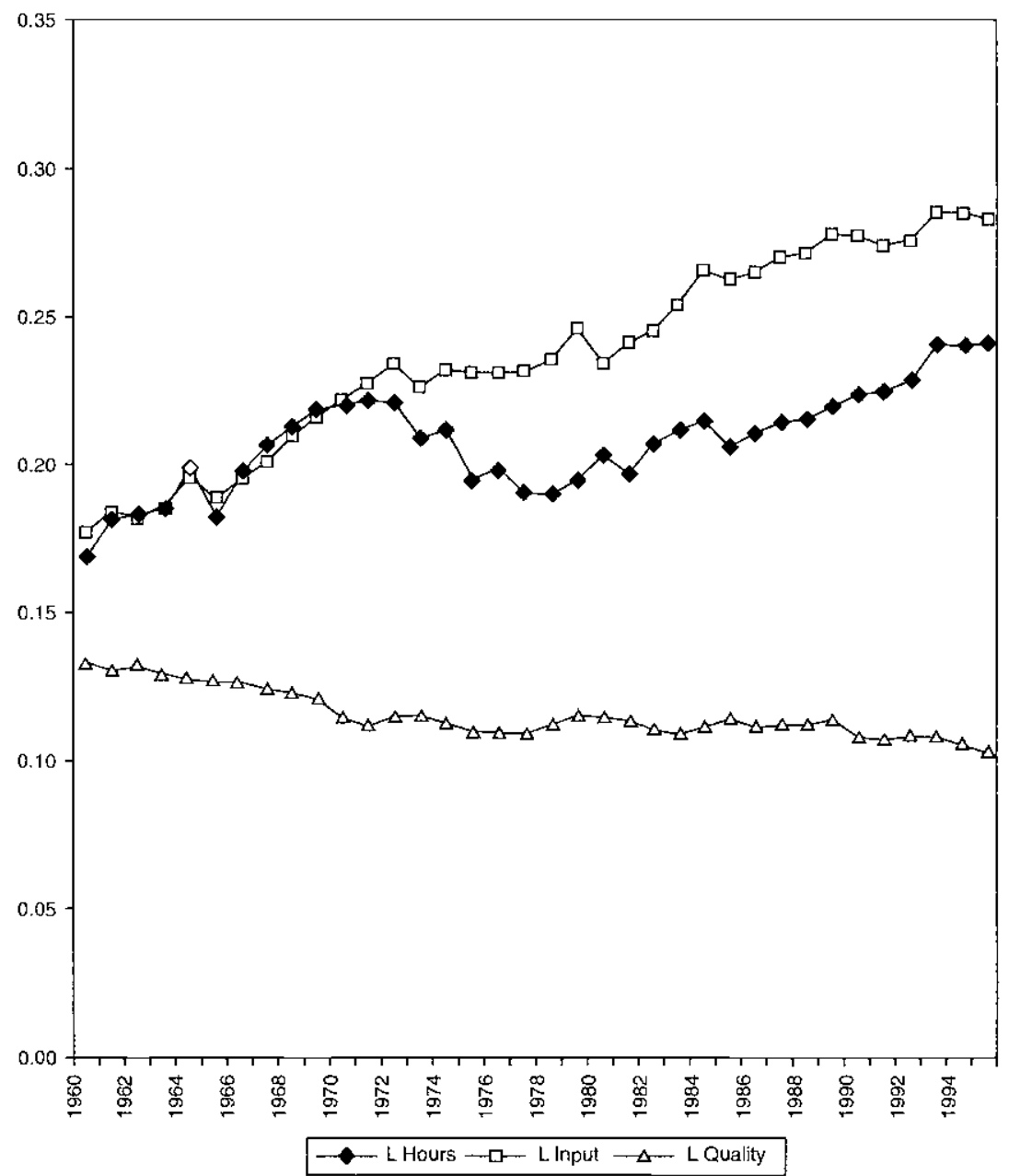

Fig. 12.3 Convergence of labor input, hours worked per capita, and labor quality 
The evidence of sigma-convergence among the G7 countries presented in figures $12.1,12.2$, and 12.3 is consistent with a new version of the neoclassical growth model, characterized by persistent but stable international differences in productivity, capital quality, labor quality, and hours worked per capita. Islam showed that a simpler version of the model with constant differences in productivity among countries successfully rationalizes differences in growth of per capita output among a much broader group of countries over the period 1960-85.

\subsection{Endogenizing Growth}

Investment is endogenous in a neoclassical growth model, whereas productivity is exogenous. Solow's (1957) definition of investment was limited to tangible assets. In order to increase the explanatory power of growth theory, it is necessary to broaden the concept of investment to include human capital. The mechanism by which investments in education and training are translated into economic growth is well understood. An increase in the supply of more highly educated or trained individuals generates a stream of labor income that represents a return to investment in human capital that can be internalized by the investor.

Constant quality indexes of labor input are an essential prerequisite for incorporating human capital into an empirical model of economic growth. The marginal products of workers with different levels of education and training are used to weight the corresponding hours of work. Jorgenson and Fraumeni (1989) have broadened the vintage accounting system developed by Christensen and Jorgenson (1973) to include investments in human capital. The essential idea is to treat individual members of the U.S. population as human assets with asset prices given by their lifetime labor incomes. Jorgenson and Fraumeni have implemented the vintage accounting system for both human and nonhuman capital for the United States on an annual basis for the period 1948-84.

In a vintage accounting system for human capital, wage rates correspond to marginal products and can be observed directly from the labor market. Lifetime labor incomes play the role of asset prices in accounting for human wealth. These incomes are derived by applying asset pricing equations to future wage rates, discounting them back to the present. Asset prices for tangible assets can be observed directly in markets for investment goods; asset pricing equations are used to derive rental prices for capital services. These rental prices are the marginal products of tangible capital assets.

Jorgenson and Fraumeni (1992b) have developed a measure of the output of the U.S. education sector. Although education is a service industry, its output is investment in human capital. Investment in education can be measured from the impact of increases in educational attainment on life- 
time incomes of individuals enrolled in school. Investment in education, measured in this way, is similar in magnitude to the value of working time for all individuals in the labor force.

Second, Jorgenson and Fraumeni (1992a) have measured the inputs of the education sector, beginning with the purchased inputs by educational institutions. Most of the value of the output of educational institutions accrues to students through increases in their lifetime incomes. Student time is the most important input into the educational process. Given the outlays of educational institutions and the value of student time, the growth of the education sector can be allocated to its sources.

An alternative approach, employed by Schultz (1961), Machlup (1962), Nordhaus and Tobin (1972), and many others, is to apply Goldsmith's (1955-56) perpetual inventory method to private and public expenditures on educational services. Unfortunately, the approach has foundered on the absence of a satisfactory measure of the output of the educational sector and the lack of an obvious rationale for capital consumption. ${ }^{17}$

Given vintage accounts for human and nonhuman capital, Jorgenson and Fraumeni (1989) constructed a system of income, product, and wealth accounts, paralleling the system Jorgenson had developed with Christensen. In these accounts the value of human wealth was more than ten times the value of nonhuman wealth, whereas investment in human capital was five times investment in tangible assets. Full investment in the U.S. economy is defined as the sum of these two types of investment. Similarly, the value of nonmarket labor activities is added to personal consumption expenditures to obtain full consumption. The product measure included these new measures of investment and consumption.

Because the complete accounting system included a production account with full measures of capital and labor inputs, ${ }^{18}$ Jorgenson and Fraumeni were able to generate a new set of accounts for the sources of U.S. economic growth. The system also included an income and expenditure account with income from labor services in both market and nonmarket activities and an allocation of full income between consumption and saving. This provided the basis for the uses of U.S. economic growth and a new measure of economic welfare. The system was completed by a wealth account containing both human wealth and tangible assets.

Jorgenson and Fraumeni aggregated the growth of education and noneducation sectors of the U.S. economy to obtain a new measure of U.S. economic growth. Combining this with measures of input growth, they obtained a new set of accounts for the sources of growth. Productivity contributes almost nothing to the growth of the education sector and only a modest proportion to output growth for the economy as a whole, so that productivity accounts for only 17 percent of growth.

17. For more detailed discussion, see Jorgenson and Fraumeni (1989).

18. Our terminology follows that of Becker's $(1965,1993)$ theory of time allocation. 
The introduction of endogenous investment in education increases the explanatory power of the theory of economic growth to 83 percent. However, it is important to emphasize that growth is measured differently. The traditional framework for economic measurement of Kuznets (1971) and Solow (1970) excludes nonmarket activities, such as those that characterize the major portion of investment in education. The intuition is familiar to any teacher, including teachers of economics: What the students do is far more important than what the teachers do, even if the subject matter is the theory of economic growth.

A third approximation to the theory of economic growth results from incorporating all forms of investment in human capital, including education, child rearing, and addition of new members to the population. Fertility could be made endogenous by using the approach of Barro and Becker (1988) and Becker and Barro (1988). Child rearing could be made endogenous by modeling the household as a producing sector along the lines of the model of the educational sector just outlined. The results presented by Jorgenson and Fraumeni (1989) show that this would endogenize 86 percent of U.S. economic growth. This is a significant, but not overwhelming, gain in explanatory power.

In principle, investment in new technology could be made endogenous within a neoclassical growth model by extending the concept of investment to encompass intellectual capital. For example, the Bureau of Economic Analysis (BEA; 1994) has provided a satellite system of accounts for research and development, based on Goldsmith's (1955-56) perpetual inventory method, applied to private and public expenditures. Unfortunately, this is subject to the same limitations as is the approach to human capital of Schultz (1961) and Machlup (1962). The BEA satellite system has foundered on the absence of a satisfactory measure of the output of R\&D and the lack of an appropriate rationale for capital consumption.

The standard model for investment in new technology, formulated by Griliches (1973), is based on a production function incorporating inputs of services from intellectual capital accumulated through R\&D investment. Intellectual capital is treated as a factor of production in precisely the same way as are tangible assets in section 12.2. Hall (1993) has developed the implications of this model for the pricing of the services of intellectual capital input and the evaluation of intellectual capital assets.

The model of capital as a factor of production first propounded by Jorgenson (1963) has been successfully applied to tangible assets and human capital. However, implementation for intellectual capital would require a system of vintage accounts including not only accumulation equations for stocks of accumulated R\&D but also asset pricing equations. These equations are essential for separating the revaluation of intellectual property due to price changes over time from depreciation of this property due to aging. This is required for measuring the quantity of intellectual capital input and its marginal product. 
The disappearance of productivity growth in the G7 countries documented in this paper is a serious challenge for theories of growth based on externalities, like those of Lucas (1988) and Romer (1986, 1990). These theories rest on spillovers of benefits that appear as productivity growth within a classification of the sources of economic growth. Externalities have become relatively less important during the period of our study. This has increased, not reduced, the explanatory power of the new version of the neoclassical theory of economic growth that we have outlined.

At this point the identification of the externalities that have contributed to past economic growth in the G7 countries is only a matter for speculation. However, a broader concept of investment is urgently required as a guide for a forward-looking growth strategy. Government policies for channeling externalities must be replaced by assignments of property rights and the design of appropriate price systems for decentralizing investment decisions among participants in the private sector. This strategy will require careful attention to the incentives facing investors in tangible assets, human capital, and intellectual property.

\section{Appendix}

\section{Data Sources}

Canada

Data on nominal and real Canadian GDP, general government output, and subsidies are available in the National Income and Expenditure Accounts (NIEA) from Statistics Canada. Labor hours and employment are available from a number of sources, including the Census, Labor Force Survey, the Input-Output Division, and the Labor Force Historical Review. The labor compensation shares by sex and educational attainment are calculated by using data of wage and salary income per employed person for Census years; non-Census years estimates are obtained by interpolation. Capital stock data are available in the NIEA and the Financial Flows Section of National Balance Sheet Accounts.

\section{France}

Data on nominal and real GDP, general government output, indirect taxes, and subsidies are available in De Compte Nationaux, Le Mouvement Economique en France (for 1949-79), and Compte et Indicateurs Economiques 1996, published by Institut National de la Statistique et des Etudes Economiques (INSEE). Data on employment by sex and educational attainment level are available in the annual Enquete de l'Emploi and Population Active, Emploi et Chomage Depuis 30 Ans, both published by 
INSEE. Data on average workweeks and weekly hours worked by sex and employment status are again available in Eurostats Labour Force Sample Survey for earlier years, and upon special request from Eurostats for 1985 onwards. French Economic Growth by Carre, Dubois, and Malinvaud provides data on annual hours worked in the 1960s. As for labor compensation shares, the French Survey of Employment, the Enquete sur la Formation et la Qualification Professionnelle, De Compte Nationaux, Le Mouvement Economique en France contains data on wages and salaries for various categories. French capital stock data can be obtained from INSEE publication Comptes de Patrimoine, De Compte Nationaux, Comptes et Indicateurs Economiques and the OECD National Accounts, volume 2. Consumer durable expenditure can be obtained in a separate account, the INSEE publication La Consommation des Menages.

\section{Germany}

Data on nominal and real GDP, general government output, indirect taxes, and subsidies are available in the Volkswirtschaftliche Gesamtrechnungen (VGR) and Statistisches Jahrbuch. Employment data can be obtained from VGR, Beruf Aubildung und Arbeitsbedingungen (for some recent years), Wirtschaft und Statistik, and Stand und Entwicklung der Erwerbstatigkeit, which contains the annual results of the German Microcensus, a household survey similar to the U.S. Current Population Survey. Labor income data are available through the Luxembourg Income Study (LIS). Most capital stock series can be found in VGR, whereas consumer durable expenditure on various categories are obtained in Einkommens und Verbrauchsstichprobe and the Laufende Wirtschaftsrechnungen.

Italy

Data on nominal and real GDP, general government output, indirect taxes, and subsidies are available in the Annuario di Contabilita Nazionale and the Conti Economici Nazionali. Employment data are available in Statistiche del Lavoro and the Rilevazione delle Forze di Lavoro. Labor hours can also be found in the Rilevazione di Lavoro, which provides data as well as from the Eurostats. The census publication Censimenti contains employment and hours data in five categories for the years 1961, 1971, 1981 and 1991. Labor compensation data are again obtained from the LIS. Capital stock data are available through the Italian business association, Confindustria, in a study carried out by Alberto Heimler; Gennaro Zezza of the Centro Studi Confindustria supplied estimates of total business inventories in 1985 prices.

Japan

Data on nominal and real GDP, general government output, indirect taxes, and subsidies are available from the National Economic Accounts, 
published by the Economic Planning Agency. The sources of data for the number of workers and employees are the Population Census of Japan, Report on the Labor Force Survey, and the Basic Survey on Wage Structures. Masahiro Kuroda of Keio University supplied the capital stock data.

\section{United Kingdom}

Data on nominal and real GDP, general government output, indirect taxes, and subsidies are available in the Blue Book published by the Central Statistical Office (CSO). Employment by sex and employment status are available in the Employment Gazette, Historical Supplement No. 2, and Employment and Earning, published by the U.K. Department of Employment, and by special request from Quantime, a subsidiary of SPSS. Data on total general government employment are available in Economic Trends, published by CSO. Data on average workweeks and weekly hours worked by sex and employment status are available in Eurostats Labour Force Sample Survey for earlier years and upon special request from Eurostats for 1985 onwards. General Household Survey provides data in labor income that can be used in calculating labor shares. Capital stock data are available in the Blue Book with the exception of data on land, which is taken from Annual Abstract of Statistics and Inland Revenue Statistics.

\section{United States}

Data on nominal and real GDP, general government output, indirect taxes, and subsidies are available in the U.S. National Income and Product Accounts, published by the Bureau of Economic Analysis. Labor hours and employment are available from the Census of Population and the Current Population Survey, published by the Bureau of the Census. The labor compensation shares by sex and educational attainment are calculated by adding estimates of fringe benefits to data on wage and salary income per employed person from the Census. Capital stock data are available from the Capital Stock Study of the Bureau of Economic Analysis and the National Balance Sheet, published by the Board of Governors of the Federal Reserve System. Further details are given by Jorgenson (1990).

\section{Other Data Sources}

Data on investment tax credits and average marginal corporate tax rates for Canada, the United Kingdom, France, Germany, and Italy are available in the data set supplied by Julian Alworth. The Institute for Fiscal Studies also provides estimates of statutory rates, and net present value of allowances for buildings and producer durable equipment for 1979 to 1994 in their recent publication Taxing Profits in a Changing World. The OECD publication Labour Force Statistics contains data on population from 1976 to 1996. Dougherty (1992) provides further details. 


\section{References}

Abramovitz, Moses. 1956. Resources and output trends in the United States since 1870. American Economic Review 46 (2): 5-23.

1986. Catching up, forging ahead, and falling behind. Journal of Economic History 46 (2): 385-406.

Aghion, Philippe, and Peter Howitt. 1998. Endogenous growth theory. Cambridge: MIT Press.

Barro, Robert J., and Gary S. Becker. 1988. Fertility choice in a model of economic growth. Econometrica 7 (2): 481-502.

Barro, Robert J., and Xavier Sala-i-Martin. 1994. Economic growth. New York: McGraw-Hill.

Baumol, William J. 1986. Productivity growth, convergence, and welfare. American Economic Review 76 (5): 1072-85.

1994. Multivariate growth patterns: Contagion and common forces as possible sources of convergence. In Convergence of productivity, ed. William J. Baumol, Richard R. Nelson, and Edward N. Wolff, 62-85. New York: Oxford University Press.

Becker, Gary S. 1965. A theory of the allocation of time. Economic Journal 75 (296): 493-517.

. 1993. Human capital. 3rd ed. Chicago: University of Chicago Press.

Becker, Gary S., and Robert J. Barro. 1988. A reformulation of the economic theory of fertility. Quarterly Journal of Economics 103 (1): 1-25.

Bureau of Economic Analysis (BEA). 1994. A satellite account for research and development. Survey of Current Business 74 (11): 37-71.

1995. Preview of the comprehensive revision of the National Income and Product Accounts: Recognition of government investment and incorporation of a new methodology for calculating depreciation. Survey of Current Business 75 (9): $33-41$.

Bureau of Labor Statistics (BLS). 1983. Trends in multifactor productivity. Bulletin no. 2178. Washington, D.C.: U.S. Department of Labor.

1993. Labor composition and U.S. productivity growth, 1948-90. Bulletin no. 2426. Washington, D.C.: U.S. Department of Labor.

Christensen, Laurits R., Dianne Cummings, and Dale W. Jorgenson. 1980. Economic growth, 1947-1973: An international comparison. In New developments in productivity measurement and analysis, ed. J. W. Kendrick and B. Vaccara, 595-698.

1981. Relative productivity levels, 1947-1973. European Economic Review 16 (1): 61-94.

Christensen, Laurits R., and Dale W. Jorgenson. 1969. The measurement of U.S. real capital input, 1929-1967. Review of Income and Wealth ser. 15, no. 4 (December): $293-320$.

1970. U.S. real product and real factor input, 1929-1967. Review of Income and Wealth ser. 16, no. 1 (March): 19-50.

1973. Measuring economic performance in the private sector. In The measurement of economic and social performance, ed. M. Moss, 233-338. New York: Columbia Press.

Denison, Edward F. 1967. Why growth rates differ. Washington, D.C.: Brookings Institution.

Dougherty, Chrys. 1992. A comparison of productivity and economic growth in the G-7 Countries. Ph.D. dissertation. Harvard University, Department of Economics. 
Dougherty, Chrys, and Dale W. Jorgenson. 1996. International comparisons of the sources of economic growth. American Economic Review 86 (2): 25-29.

-1997. There is no silver bullet: Investment and growth in the G7. National Institute Economic Review 162 (October): 57-74.

Douglas, Paul H. 1948. Are there laws of production? American Economic Review 38 (1): 1-41.

Fraumeni, Barbara M. 1997. The measurement of depreciation in the U.S. National Income and Wealth Accounts. Survey of Current Business. Vol. 77 (7) 7-23.

Gilbert, Milton, and Irving B. Kravis. 1954. An international comparison of national products and the purchasing power of currencies. Paris: Organization for European Economic Cooperation.

Goldsmith, Raymond. 1955-56. A Study of Saving in the United States, 3 vols. Princeton: Princeton University Press.

. 1962. The national wealth of the United States in the postwar period. New York: National Bureau of Economic Research.

Gordon, Robert J. 1990. The measurement of durable goods prices. Chicago: University of Chicago Press.

Greenwood, Jeremy, Zvi Hercowitz, and Per Krusell. 1997. Long-run implications of investment-specific technological change. American Economic Review 87 (3): 341-62.

Griliches, Zvi. 1960. Measuring inputs in agriculture: A critical survey. Journal of Farm Economics 40 (5): 1398-1427.

- 1973. Research expenditures and growth accounting. In Science and technology in economic growth, ed. B. Williams, 59-95. London: Macmillan.

. 1992. The search for R\&D spillovers. Scandinavian Journal of Economics 94 (supplement): 29-47.

. 1995. R\&D and productivity: Econometric results and measurement issues. In Handbook of the economics of innovation and technological change, ed. P. Stoneman, 52-89. Oxford: Basil Blackwell.

Grossman, Gene M., and Elhanan Helpman. 1991. Innovation and growth. Cambridge: MIT Press.

- 1994. Endogenous innovation in the theory of growth. Journal of Economic Perspectives 8 (1): 23-44.

Hall, Bronwyn H. 1993. Industrial research in the 1980s: Did the rate of return fall? Brookings Papers on Economic Activity, Microeconomics: (2): 289-331.

Hall, Robert E. 1971. The measurement of quality change from vintage price data. In Price indexes and quality change, ed. Z. Griliches, 240-71. Cambridge: Harvard University Press.

Hall, Robert E., and Charles I. Jones. 1999. Why do some countries produce so much more output per worker than others? Quarterly Journal of Economics 114 (1): 83-116.

Hall, Robert E., and Dale W. Jorgenson. 1967. Tax policy and investment behavior. American Economic Review 57 (3): 391-414.

- 1969. Tax policy and investment behavior: Reply and further results. American Economic Review 59 (3): 388-401.

- 1971. Applications of the theory of optimal capital accumulation. In Tax incentives and capital spending, ed. G. Fromm, 9-60. Amsterdam: NorthHolland.

Ho, Mun S., and Dale W. Jorgenson. 1999. The quality of the U.S. work force, 1948-95. Harvard University, Department of Economics. Manuscript.

Hulten, Charles R., and Frank C. Wykoff. 1982. The measurement of economic 
depreciation. Depreciation, inflation and the taxation of income from capital, ed. C. R. Hulten, 81-125. Washington, D.C.: Urban Institute Press.

Inter-Secretariat Working Group on National Accounts. 1993. In System of $\mathrm{Na}$ tional Accounts 1993, 379-406. New York: United Nations.

Islam, Nazrul. 1995. Growth empirics. Quarterly Journal of Economics 110 (4): 1127-70.

Jorgenson, Dale W. 1963. Capital theory and investment behavior. American Economic Review 53 (2): 247-59. $1-17$. 1966. The embodiment hypothesis. Journal of Political Economy 74 (1):

1967. The theory of investment behavior. In Determinants of investment behavior, ed. R. Ferber, 247-59. New York: Columbia University Press.

. 1990. Productivity and economic growth. In Fifty years of economic measurement, ed. E. R. Berndt and J. Triplett, 19-118. Chicago: University of Chicago Press.

. 1996. Empirical studies of depreciation. Economic Inquiry 34 (1): 24-42.

Jorgenson, Dale W., and Barbara M. Fraumeni. 1989. The accumulation of human and nonhuman capital, 1948-1984. In The measurement of saving, investment, and wealth, ed. R. E. Lipsey and H. S. Tice, 227-82. Chicago: University of Chicago Press.

1992a. Investment in education and U.S. economic growth. Scandinavian Journal of Economics 94 (supplement): 51-70.

1992b. The output of the education sector. In Output measurement in the services sector, ed. Z. Griliches, 303-38. Chicago: University of Chicago Press.

Jorgenson, Dale W., Frank M. Gollop, and Barbara M. Fraumeni. 1987. Productivity and U.S. economic growth. Cambridge: Harvard University Press.

Jorgenson, Dale W., and Kevin J. Stiroh. 1995. Computers and growth. Economics of Innovation and New Technology 3 (3-4): 295-316.

(2): $109-15$.

Jorgenson, Dale W., and Zvi Griliches. 1967. The explanation of productivity change. Review of Economic Studies 34 (99): 249-80.

Kravis, Irving B., Alan Heston, and Robert Summers. 1978. International comparisons of real product and purchasing power. Baltimore: Johns Hopkins University Press.

Kuznets, Simon. 1961. Capital in the American economy. Princeton: Princeton University Press.

- 1971. Economic growth of nations. Cambridge: Harvard University Press.

Levine, Ross, and David Renelt. 1992. A sensitivity analysis of cross-country regressions. American Economic Review 82 (4): 942-63.

Lucas, Robert E. 1988. On the mechanics of economic development. Journal of Monetary Economics 22 (1): 2-42.

Machlup, Fritz. 1962. The production and distribution of knowledge in the United States. Princeton: Princeton University Press.

Maddison, Angus. 1982. Phases of capitalist development. Oxford: Oxford University Press.

. 1991. Dynamic forces in capitalist development. Oxford: Oxford University Press.

. 1995. Monitoring the world economy. Paris: Organization for Economic Cooperation and Development.

Mankiw, N. Gregory, David Romer, and David Weil. 1992. A contribution to the empirics of economic growth. Quarterly Journal of Economics 107 (2): 407-37. 
Mincer, Jacob. 1974. Schooling, experience, and earnings. New York: Columbia University Press.

Nordhaus, William D., and James Tobin. 1972. Is growth obsolete? In The measurement of economic and social performance, ed. M. Moss, 509-32. New York: Columbia University Press.

Romer, Paul. 1986. Increasing returns and long-run growth. Journal of Political Economy 94 (5): 1002-37.

1987. Crazy explanations for the productivity slowdown. In NBER macroeconomics annual, ed. Stanley Fischer, 163-201. Cambridge: MIT Press. 1990. Endogenous technological change. Journal of Political Economy 98 (5, pt. 2): S71-S102.

1994. The origins of endogenous growth. Journal of Economic Perspectives 8 (1): 3-20.

Samuelson, Paul A. 1961. The evaluation of "social income": Capital formation and wealth. In The theory of capital, ed. F. A. Lutz and D. C. Hague, 32-57. London: Macmillan.

Schultz, Theodore W. 1961. Investment in human capital. American Economic Review 51 (1): 1-17.

Solow, Robert M. 1956. A contribution to the theory of economic growth. Quarterly Journal of Economics 70 (1): 65-94.

. 1957. Technical change and the aggregate production function. Review of Economics and Statistics 39 (3): 312-20.

1960. Investment and technical progress. In Mathematical methods in the social sciences, ed. K. J. Arrow, S. Karlin, and P. Suppes, 89-104. Stanford: Stanford University Press.

- 1970. Growth theory: An exposition. New York: Oxford University Press. 1992. Growth theory. 2nd ed. New York: Oxford University Press.

Stone, Richard. 1992. The accounts of society. In Nobel lectures: Economic sciences, 1981-1990, ed. K. G. Maler, 115-39. River Edge, N.J.: World Scientific.

Summers, Robert, and Alan Heston. 1984. Improved international comparisons of real product and its composition: 1950-1980. Review of Income and Wealth ser. 30, no. 1 (March): 1-25.

1988. A new set of international comparisons of real product and price levels: Estimates for 130 countries, 1950-1985. Review of Income and Wealth ser. 34, no. 1 (March): 19-26.

1991. The Penn World Table (Mark 5): An expanded set of international comparisons, 1950-1988. Quarterly Journal of Economics 106 (2): 327-68.

Tinbergen, Jan. 1959. On the theory of trend movements. In Jan Tinbergen, selected papers, trans. Hans Wilke, 182-221. Amsterdam: North-Holland. (Originally published as Tinbergen, Jan. 1942.) Zur theorie der langfristigen wirtschaftsentwicklung. Weltwirtschaftliches Archiv 55 [1]: 511-49.

Triplett, Jack. 1996. Measuring the capital stock: A review of concepts and data needs. Economic Inquiry 34 (1): 36-40.

United Nations (UN). 1968. A system of national accounts. New York: UN.

World Bank. 1994. World development report 1993. Washington, D.C.: World Bank. 